\title{
Gastroprotective effects of essential oil from Protium heptaphyllum on experimental gastric ulcer models in rats
}

\author{
Deborah A. O. Valim Araujo, ${ }^{* 1}$ Christiane Takayama, ${ }^{2}$ Felipe \\ M. de-Faria, ${ }^{2}$ Eduardo A. R. Socca, ${ }^{2}$ Ricardo J. Dunder, ${ }^{2}$ Luis \\ P. Manzo, ${ }^{2}$ Anderson Luiz-Ferreira, ${ }^{2}$ Alba R. M. Souza-Brito ${ }^{2}$
}

\author{
${ }^{1}$ Departamento de Farmacologia, Faculdade de Ciências Médicas Universidade \\ Estadual de Campinas, Brazil, \\ ${ }^{2}$ Departamento de Anatomia, Biologia Celular e Fisiologia e Biofísica, Instituto de \\ Biologia, Universidade Estadual de Campinas, Brazil.
}

\begin{abstract}
Peptic ulcers are a common disorder of the entire gastrointestinal tract, its etiology has not been completely elucidated. The basic physiopathological of peptic ulcers result from an imbalance between some endogenous aggressive factor and cytoprotective factors. The treatment of this disease is usually done with antacids or proton pump, but are currently being used plants derivated compounds. We evaluated the gastroprotective properties and its possible mechanisms of action of the essential oil from Protium heptaphyllum (Aubl.) Marchand, Burseraceae (BB). The formation of ulcers, were evaluated in three experimental models, through the induction of gastric lesions by ethanol, nonsteroidal anti-inflammatory drugs and acetic acid. The mechanisms of action were evaluated through the pylorus ligature experiment, western blot, GSH, GR, SOD, GPx, MDA and MPO activities. BB significantly inhibited the formation of ulcers induced by the three different models, increased the GSH and GR levels and maintained the same levels of SOD and GPx of the sham group, inhibited MPO and MDA, did not produce significant modification in gastric juice content and showed increased COX-2 and EGF. BB exerts its gastroprotective activity, possibly, by increasing COX-2 and EGF expression and due to its possible antioxidant property.
\end{abstract}

Revista Brasileira de Farmacognosia Brazilian Journal of Pharmacognosy 21(4): 721-729, Jul./Aug. 2011

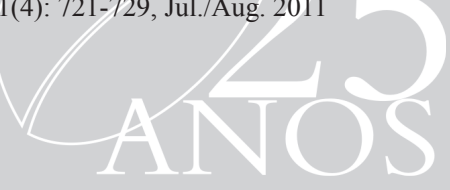

\section{Article}

Received 10 Aug 2010

Accepted 1 Jan 2011

Available online 8 Jul 2011

Keywords: essential oil gastric ulcer

Protium heptaphyllum

ISSN 0102-695X

doi: 10.1590/S0102-695X2011005000117

\section{Introduction}

Peptic ulcer is a common disorder of the entire gastrointestinal tract, they occur mainly in the stomach and the proximal duodenum (Mayty et al., 2003). Despite great advances in the understanding of the peptic ulcer illness, its etiology has not been completely elucidated. The basic physiopathological of gastric ulcer results from an imbalance between some endogenous aggressive factor(s) [hydrochloric acid, pepsin, refluxed bile, leukotrienes, reactive oxygen species (ROS)] and cytoprotective factors, which include the function of the mucus-bicarbonate barrier, surface active phospholipids, prostaglandins (PG), mucosal blood flow, cell renewal and migration, nonenzymatic and enzymatic antioxidants and some growth factors (Bandyopadhyay et al., 2001; Bhattacharjee et al., 2002).

Although recent advances in our understanding have highlighted the multi-factorial pathogenesis of peptic ulcers, secretion of gastric acid is still recognized as a central component of this disease. Therefore, the main therapeutic target is the control of this secretion using antacids, H2 receptor blockers (ranitidine, famotidine) or proton pump blockers (omeprazole and lansoprazole) (Rao et al., 2004). However, nowadays, gastric ulcer therapy faces a major drawback because most of the drugs currently available in the market show limited efficacy against gastric diseases and are often associated with severe side effects (Bandyopadhyay et al., 2002; Lehne, 1998).

In this context, the use of medicinal plants for the prevention and treatment of different pathologies is in continuous expansion worldwide (Mota et al., 2009). Natural products are gaining space and importance in the pharmaceutical industry as well as inspiring the search for new potential sources of bioactive molecules (Cechinel-Filho \& Yunes, 2001; Schmeda-Hirschmann \& Yesilada, 2005). The natural active compounds classes or secondary metabolites as alkaloids, flavonoids, terpenoids, tannins and others have attracted researchers to investigate their chemical, toxicological and pharmacological features. Some plants studied showed efficacy against gastric ulcers 
such as: Anacardium humile have shown to possess antiulcerogenic activity (Luiz-Ferreira et al., 2010), as well as Vernonia polyanthes (Barbastefano et al., 2007), among others.

Protium heptaphyllum (Aubl.) Marchand, Burseraceae, is a medicinal plant largely found in the North and Northeast of Brazil, it is popularly known as "breu branco", and popularly used for inflammations, pain, ulcers and wounds. The triterpenes isolated from several species of medicinal plants are, in general, responsible, at least in part, for their biological activities (Aragão et al., 2006), including anti-inflammatory, anti-ulcer, anti-hyperlipidemic, anti-tumor, and hepatoprotective (Oliveira et al., 2005). Essential oils are complex mixtures comprising many single compounds, chemically derived from terpenes and their oxygenated compounds, these constituents contribute to the antifungal, antiviral, antioxidant effects (Laciar et al., 2009; Aidi et al., 2010). The present study aims to characterize the anti-ulcerogenic activity of the essential oil of Protium heptaphyllum March (BB) in three distinct induced gastric ulcer models: ethanol, Non Steroidal Anti Inflammatory Drugs and acetic acid as well as the mechanisms of action.

\section{Materials and Methods}

\section{Animal}

Male Wistar rats Unib: WH, (n=7, 180-250 g), were obtained from the Central Animal House of the State University of Campinas (CEMIB/Unicamp). Animals were fed a certified Nuvilab ${ }^{\circledR}$ (Nuvital) diet, with free access to tap water, and were housed on a $12 \mathrm{~h}$ light/dark cycle at $60 \pm 1 \%$ humidity and a temperature of $21 \pm 2{ }^{\circ} \mathrm{C}$. The experimental protocols were all approved by the Institutional Committee for Ethics in Animal Experimentation of the Institute of Biology in the State University of Campinas ( $\mathrm{n}^{\circ} 852-1$, CEEA/IB/ Unicamp).

\section{Essential oil}

The BB was purchased from Laszlo aromaterapia Ltda. and was obtained from leaves and stem from this specimen by steam distillation. Parts of Protium heptaphyllum (Aubl.) Marchand, Burseraceae, were collected in the river delta Jequiriçá in the city of Valença, Bahia state (BA), Brazil by Antonio Calmon. An authenticated "voucher" specimen was identified by Jorge Yoshio Tamashiro of Unicamp and deposited under the number 151890 at UEC herbarium (Campinas, SP-Brazil).

\section{Identification of essential oil constituents}

The BB samples were analyzed in a gas chromatographer coupled to an electronic $(70 \mathrm{eV})$ mass spectrometer (GC-MS, Shimadzu, GC-2010) equipped with a capillary column of fused silica (DB-5; 5.30 $\mathrm{m} \times 0.32 \mathrm{~mm} \times 0.25 \mu \mathrm{m})$, helium as the carrier gas (1.52 $\mathrm{mL} / \mathrm{min}$, White Martins, 99.9\%), injector at 250 ${ }^{\circ} \mathrm{C}$, detector at $250{ }^{\circ} \mathrm{C}$ and split injection mode. Mass spectrum acquisition was performed at a mass range from 40 to $600 \mathrm{~m} / \mathrm{z}$. The essential oil $(10 \mu \mathrm{L})$ was diluted in chloroform to produce $1 \mathrm{~mL}$ of chromatographic grade solvent, $1 \mu \mathrm{L}$ of which was injected as sample at the split ratio of $1: 30$. The column temperature was heated to $60{ }^{\circ} \mathrm{C}$ and programmed at $5{ }^{\circ} \mathrm{C} / \mathrm{min}$ to 220 ${ }^{\circ} \mathrm{C}$. The identification of substances was performed by the comparison of its mass spectra with the GC-MS system database (NIST 62 lib.), the literature and with the Kovats retention indices.

\section{Drugs}

The following drugs were used: lansoprazole (Medley, Campinas-SP, Brazil), Tween $80^{\circledR}$ and acetic acid (Sinth, SP, Brasil), absolute ethanol ( ${ }^{\circ}$ Merck KGaA, Darmstadt, Germany), cimetidine, carbenoxolone, indomethacin, were from Sigma Chemical Co. (St. Louis, USA). All reagents were of high grade of purity. The BB was dissolved in a $12 \%$ Tween $80^{\circledR}$ solution $(\mathrm{w} / \mathrm{v})$. The substances were prepared just before use.

\section{Ethanol-induced gastric lesions}

Ethanol-induced ulcers were evaluated in rats according to Morimoto (Morimoto et al., 1991). Rats fasted for $24 \mathrm{~h}$ were treated with BB $(12.5,25,50$ and $100 \mathrm{mg} / \mathrm{kg}$ ), lansoprazole (30 mg/kg) or vehicle $12 \%$ Tween $80^{\circledR}(10 \mathrm{~mL} / \mathrm{kg})$. One hour after treatment all the animals received, orally, $1 \mathrm{~mL} / \mathrm{kg}$ of absolute ethanol. Animals were killed by cervical dislocation one hour after ethanol administration, their stomachs removed, opened along the great curvature and fixed between two glass plates. The inner surface of the stomach was examined with a dissecting microscope (Nikon SMZ 800) and photographed with a Nikon Coolpix 4500 camera for later computer analysis. The total ulcerated area in the stomach corpus was measured with Bioview 4 (AvSoft, Brazil) an image analysis software (Khan, 2004).

Non steroidal anti-inflammatory drugs (NSAID) induced gastric lesions

In this model, the gastric ulcer was induced using indomethacin $(100 \mathrm{mg} / \mathrm{kg})$, administered to rats after $36 \mathrm{~h}$ fast. BB $(100 \mathrm{mg} / \mathrm{kg})$, cimetidine $(100 \mathrm{mg} / \mathrm{kg})$ or vehicle $12 \%$ Tween $80(10 \mathrm{~mL} / \mathrm{kg})$ was administered 
orally, $30 \mathrm{~min}$ before the induction of gastric ulcer. The animals were killed by cervical dislocation $5 \mathrm{~h}$ after ulcer induction (Puscas et al., 1997). Their stomachs were removed and analyzed as previously described.

\section{Chronic ulcer and toxicity evaluation}

The experiments were carried out according to the method described by Takagi (Takagi et al., 1969) with some modifications in Okabe (Okabe \& Amagase, 2005). Rats fasted for $24 \mathrm{~h}$, under anaesthesia with ketamine and xylazine, a laparotomy was done in all animals through a midline epigastric incision. After exposing the stomach, one small tube was placed on the stomach, in the serosa region with an acetic acid solution $100 \%$ for $1 \mathrm{~min}$. The abdomen was then closed and all the animals were fed normally. Two days after surgery, the treatment started: oral administration of BB (100 mg/kg), carbenoxolon (100 mg/kg) and vehicle Tween $8012 \%(10 \mathrm{~mL} / \mathrm{kg})$, once a day for fourteen consecutive days. On the day after the last drug administration, the rats were killed by cervical dislocation, the stomachs removed and analyzed as described above. The toxicological parameters were set according to the method of Souza-Brito 1994 (SouzaBrito, 1994). The toxicity in the animals submitted to BB $(100 \mathrm{mg} / \mathrm{kg})$ treatment was evaluated for a period of fourteen days. The body weight progression, hair and mucosal alteration were observed daily. The following organs were weighed to detect any effect of the essential oil on their individual weights: heart, lungs, liver and kidneys.

\section{Gastric secretion in pylorus ligature induced lesions}

The method described by Shay (Shay et al., 1945), was used with some modifications. Rats were fasted for $36 \mathrm{~h}$. Immediately after pylorus ligature, BB $(100 \mathrm{mg} / \mathrm{kg})$, cimetidine $(100 \mathrm{mg} / \mathrm{kg})$ and vehicle Tween 80 12\% (10 mL/kg) were administered orally and intraduodenally. Rats were killed $4 \mathrm{~h}$ later, their abdomens were opened and their stomachs removed. The amount of the gastric juice $(\mathrm{mL})$ and its $\mathrm{pH}$ were determined using a pH-meter (PA 200, Marconi S.A., Piracicaba, Brazil).

\section{Western blot assay}

Frozen glandular stomachs samples were homogenized in $1 \mathrm{~mL}$ of ice cold phosphate buffer (PB $0.1 \mathrm{M}, \mathrm{pH} 7.4$ and protease inhibitor $1 \%$ ). Homogenates were centrifuged (12000 g $15 \mathrm{~min}, 4{ }^{\circ} \mathrm{C}$ ) and the supernatants were collected and stored at $-80^{\circ} \mathrm{C}$. Protein concentration of the homogenate was determined following Bradford's colorimetric method (Bradford,
1976). Then, samples were treated with Laemmili buffer (PB 0.5 M, pH 6.8; glycerol, sodium dodecyl sulphate (SDS) $10 \%$, bromophenol $0.1 \%, \beta$-mercaptoethanol) in a $1: 1$ proportion. Equal amounts of protein from samples $(100 \mu \mathrm{g})$ were separated on $10 \%$ acrylamide gel by sodium dodecyl sulphate polyacrylamide gel electrophoresis. In the next step, proteins were electrophoretically transferred onto a nitrocellulose membrane and incubated with specific primary antibodies: EGF (Santa Cruz Biotechnology, Inc, USA) and COX-2 (Cayman Chemical, USA) at dilution of 1:500. Each membrane was washed three times for 10 min and incubated with anti-goat immunoglobulin $\mathrm{G}$ antibody (Zymed Laboratories, USA) for EGF and with anti-rabbit (Zymed Laboratories, USA) for COX-2, both at dilution of 1:5000. To prove equal loading, the blots were analyzed for $\beta$-actin expression using an anti- $\beta$-actin antibody (Sigma-Aldrich, MO, USA). Immunodetection was performed using enhanced chemiluminiscence light-detecting kit (SuperSignal ${ }^{\circledR}$ West Femto Chemiluminescent Substrate, Pierce, IL, USA). Densiometric data were performed following normalization to the control (housekeeping gene) by AVSoft program.

\section{Antioxidant activity}

All tissues used in these antioxidant experiments were obtained from models of gastric ulcer induced by ethanol (Morimoto et al., 1991).

\section{Glutathione peroxidase (GPx)}

The activity of GPx in the gastric mucosa was evaluated spectrophotometrically at $365 \mathrm{~nm}$. The absorbances were read at each minute between 1 and $10 \mathrm{~min}$. This assay is based on the oxidation of the reduced glutathione by glutathione peroxidase coupled to the oxidation of NADPH by glutathione reductase. The tissue homogenate was diluted in phosphate buffer (PB) $(1: 10) .100 \mu \mathrm{L}$ of this solution was mixed with $50 \mu \mathrm{L} \mathrm{H}_{2} \mathrm{O}_{2}(0.25 \mathrm{mM}), 20 \mu \mathrm{L}$ of reduced glutathione $(10 \mathrm{mM}), 20 \mu \mathrm{L}$ NADPH $(4 \mathrm{mM}), 10 \mu \mathrm{L}(1 \mathrm{U})$ of glutathione reductase. The new solution was diluted again in PBS, pH 7.8 (Yoshikawa et al., 1993).

Glutahione redutase (GR)

GR activity was determined spectrophotometrically by measuring the rate of NADPH oxidation at $340 \mathrm{~nm}$ (Carlberg \& Mannervick, 1985). Results are expressed as the amount of enzyme that catalyses the oxidation of $1 \mu \mathrm{mol}$ of $\mathrm{NADPH}$ per minute per milligram of tissue $\left(\mu \mathrm{mol} / \mathrm{min}^{-1} / \mathrm{mg}\right.$ tissue $\left.^{-1}\right)$. 


\section{Superoxide dismutase (SOD)}

The SOD activity was assessed by the inhibition of the reduction of nitro blue tetrazolium (NBT) by the generated superoxide radical through the hypoxanthine/ xanthine oxidase system (XO) at $37{ }^{\circ} \mathrm{C}$. The enzymatic reaction was composed of: $\mathrm{PB} 0.1 \mathrm{M} ; \mathrm{pH} 7.4 ; 0.07 \mathrm{U}$ of $\mathrm{XO} \mathrm{mL} ; 100 \mu \mathrm{M}$ hypoxanthine; $600 \mu \mathrm{M}$ NBT and $1 \mathrm{mg} /$ $\mathrm{mL}$ of protein from the sample (Winterbourn et al., 1995).

\section{Mieloperoxidase (MPO)}

The MPO activity in the gastric mucosa was determined according to the method of Winterbourn (Winterbourn et al., 1995). After the experiment of inducing ulcer with absolute ethanol, a portion of the glandular stomach of the animals was shaved and suspended in $1 \mathrm{~mL}$ of sodium phosphate buffer $0.05 \mathrm{M}$ $\mathrm{pH}$ 6.8. The tissue was homogenized and centrifuged at $4{ }^{\circ} \mathrm{C}, 12000 \mathrm{x} g$, for $15 \mathrm{~min}$ and the supernatant was analyzed. The absorbances were read at $460 \mathrm{~nm}$ at each minute between 1 and $10 \mathrm{~min}$. The results were expressed in $\mathrm{U} / \mathrm{g}$ of protein.

\section{Sulfhydryl group (GSH)}

The samples were centrifuged (12000 x $g, 4$ ${ }^{\circ} \mathrm{C}$ for $15 \mathrm{~min}$.) and the supernatant diluted $(1: 10)$ in sodium phosphate buffer (0. $1 \mathrm{M}, \mathrm{pH} 7.4)$. Then, a reading was made based on the absorbance of $100 \mu \mathrm{L}$ of sample plus $100 \mu \mathrm{L}$ of Tris solution $(1.0 \mathrm{mM})$ and EDTA $(0.02 \mathrm{mM})$ at $412 \mathrm{~nm}$ (A1). After the reading, $20 \mu \mathrm{L}$ of (5.5 ditiobis 2-nitrobenzoic) acid (DTNB 0.01 $\mathrm{mM}$ ) was added, dissolved in methanol and has been re-read (A2) at $412 \mathrm{~nm}$ after $15 \mathrm{~min}$. of reaction. The concentration of sulfhydryl group (thiol) is given by (A1-A2) x 1.57 (Faure \& Lafond, 1995).

\section{Determination of lipid peroxidation or malondialdehyde (MDA) formation}

The concentrations of gastric mucosal lipid peroxidation were determined by estimating malondialdehyde using the thiobarbituric acid test (Ohkawa et al., 1979). The stomachs of the rats were promptly excised and rinsed with cold saline. To minimize the possibility of hemoglobin's interference with free radicals, any blood adhering to the mucosa was carefully removed. The gastric mucosa was scraped, weighed, and homogenized in $10 \mathrm{~mL}$ of 100 $\mathrm{g} / \mathrm{L} \mathrm{KCl}$. The homogenate $(0.5 \mathrm{~mL})$ was added to a solution containing $0.2 \mathrm{~mL}$ of $80 \mathrm{~g} / \mathrm{L}$ sodium lauryl sulfate, $1.5 \mathrm{~mL}$ of $200 \mathrm{~g} / \mathrm{L}$ acetic acid, $1.5 \mathrm{~mL}$ of $8 \mathrm{~g} / \mathrm{L}$ 2-thiobarbiturate, and $0.3 \mathrm{~mL}$ of distilled water. This mixture was heated at $98{ }^{\circ} \mathrm{C}$ for $1 \mathrm{~h}$. and after cooled, 5
mL of $n$-butanol:pyridine $(15: 1)$ was added. The mixture was vortexed for $1 \mathrm{~min}$. and centrifuged for $30 \mathrm{~min}$. at $4000 \times \mathrm{g}$. The supernatant absorbance was measured at $532 \mathrm{~nm}$. The standard curve was obtained by using 1,1,3,3-tetramethoxypropane. The recovery was over $90 \%$. The results were expressed as nanomoles of MDA per gram of wet tissue (nmol/g tissue).

\section{Statistical analysis}

Results were expressed as the mean \pm SEM. Statistical significance was determined by one-way analysis of variance (ANOVA) followed by Dunnett's or Tukey's post-hoc test, with the minimum level of significance set at $p<0.05$.

\section{Results and Discussion}

Although there are many products in the market for the treatment of gastric ulcers, including antacids, proton pump inhibitors, anticholinergics and histamine $\mathrm{H} 2$-antagonists, most of these drugs produce several adverse reactions, such as gynecomastia, hematopoietic changes, acute interstitial nephritis, thrombocytopenia anaphylaxis reactions, nephrotoxicity and hepatotoxicity. In developing countries the peptic ulcer treatment is very expensive, thus, there is a growing need for less expensive antiulcer agents with minor side effects. In this context, medicinal plants are amongst the most attractive sources of new drugs, and have been shown to give promising results in the treatment of gastric ulcers. In Brazil, a large number of herbal extracts is used in folk medicine to treat various types of digestive disorders (Hiruma-Lima et al., 2006). We studied the gastroprotective effect of the BB and its possible mechanisms of action.

In the present investigation, the GC-MS analysis revealed that the components of the $\mathrm{BB}$ are $\alpha$-pinene $40 \%$, followed by $p$-mentha-1.4(8)-diene $12 \%$ and $\alpha$-phellandrene $10 \%$ and thirteen components in lower concentrations (Table 1), thus revealing that this oil is composed mainly by monoterpenes. Monoterpenic essential oils are considered natural antioxidants due to the presence of $\alpha$-pinene (Singh et al., 2010; Aidi et al., 2010).

Oral administration of absolute ethanol is noxious to the stomach since it affects the gastric mucosa topically by disrupting its barrier and provoking pronounced microvascular changes within a few minutes after its application (Moleiro et al., 2009). Even oral administration of absolute ethanol to rats produced linear hemorrhagic lesions, extensive submucosal edema, mucosal friability, inflammatory cells infiltration, and epithelial cell loss in the stomach, which are typical characteristics of alcohol injury 
(Franke et al., 2005). The pathogenesis of ethanolinduced gastric mucosal damage occurs directly and indirectly through various mediators such lipoxygenase, cytokines, and oxygen-derived free radicals (Abdel-Salam et al., 2001). Oral administration of BB (12.5, 25, 50 and $100 \mathrm{mg} / \mathrm{kg}$ ) inhibited ethanol-induced gastric lesions by 4, 45, 46 and $96 \%$ respectively. When compared to the control value, BB significantly inhibited ulcerative lesions at the dose of $100 \mathrm{mg} / \mathrm{kg}$, therefore this dose was used in all other experiments (Table 2).

Table 1. Chemical composition (percentage) of essential oils extracted from Protium heptaphyllum using analysis by GC-MS.

\begin{tabular}{cccc}
\hline Peak & RT & Compound & Composition\% \\
\hline 1 & 4,283 & $\alpha$-thujene & 1,03 \\
2 & 4,435 & $\alpha$-pinene & 40,32 \\
3 & 4,734 & camphene & 1,32 \\
4 & 5,311 & sabinene & 0,12 \\
5 & 5,376 & $\beta$-pinene & 4,78 \\
6 & 5,448 & $p$-menth-2-ene & 0,1 \\
7 & 5,765 & $\beta$-myrcene & 0,11 \\
8 & 5,919 & carane & 2,36 \\
9 & 6,062 & $\alpha$-phellandrene & 10,27 \\
10 & 6,208 & 3 -carene & 5,78 \\
11 & 6,377 & 2-carene & 2,31 \\
12 & 6,582 & $p$-cimene & 9,64 \\
13 & 6,696 & $m$-mentha-1,8-diene & 8,88 \\
14 & 7,518 & $\delta$-terpinene & 0,66 \\
15 & 8,322 & $p$-mentha-1,4(8)-diene & 12,14 \\
16 & 9,841 & camphor & 0,18 \\
\hline
\end{tabular}

RT- Retention time

Table 2. Effect of BB on gastric lesions induced by ethanol and indomethacin in rats. Results were expressed as mean $\pm \mathrm{SEM}$. Data were analyzed by ANOVA followed by Tukey's test and compared to vehicle. ${ }^{*} p<0.01 * * p<0.001$.

\begin{tabular}{lccc}
\hline \multicolumn{1}{c}{ Treatments (p.o.) } & $\begin{array}{c}\text { Dose } \\
(\mathrm{mg} / \mathrm{kg})\end{array}$ & $\begin{array}{c}\text { Damage } \\
\text { Area }\left(\mathrm{mm}^{2}\right)\end{array}$ & $\begin{array}{c}\text { Gastroprotection } \\
\%\end{array}$ \\
\hline $\begin{array}{l}\text { Ethanol-induced gastric } \\
\text { lesions }\end{array}$ & & & \\
Vehicle & 10 & $104.3 \pm 19.3$ & - \\
Lansoprazole & 30 & $40.5 \pm 5.9 *$ & 38.8 \\
BB & 12.5 & $99.9 \pm 6.9$ & 4.2 \\
& 25 & $56.7 \pm 11.4$ & 54.3 \\
& 50 & $56.4 \pm 20.0$ & 54.0 \\
& 100 & $4.1 \pm 1.0^{* *}$ & 96.0 \\
Indomethacin-induced & & & \\
gastric lesions & & & - \\
Vehicle (mL/kg) & 10 & $29.9 \pm 13.5$ & 96.9 \\
Cimetidine & 100 & $0.9 \pm 0.4^{* *}$ & 96.9 \\
BB & 100 & $0.9 \pm 0.1 * *$ & \\
\hline
\end{tabular}

It is well known that indomethacin is used not only as an anti-inflammatory drug but also to induce an experimental ulcer model in rats (Polat et al., 2010), due to the fact that this compound inhibits the synthesis of cytoprotective prostaglandins, synthesized by COX-1 and COX-2 in the stomach tissue. Furthermore, it's also been shown that reactive oxigen species (ROS) play an important role in the pathogenesis of mucosal damages caused by indomethacin (Odabasoglu et al., 2006). Oral treatment with $\mathrm{BB}(100 \mathrm{mg} / \mathrm{kg})$ reduced the indomethacin- induced gastric lesion by $95 \%$ (Table 2).

Ulcer healing, a genetically programmed repair process, includes inflammation, cell proliferation, reepithelialization, formation of granulation tissue, angiogenesis, interactions between various cells and the matrix and tissue remodeling, all resulting in scar formation, the capacity to accelerate the ulcer healing process depends on many factors, like the epidermal growth factor (EGF), fibroblast growth factor (bFGF), vascular endothelial growth factor (vEGF), trefoil peptides and COX-2 in a well synchronized spatial and temporal manner (Tarnawski, 2005). Regarding the COX-2 (Figure 1A) and EGF (Figure 1B) expression, Western Blotting analysis in the present study shows a great quantity of both in the gastric mucosa of animals treated with $\mathrm{BB}$.

It has been shown that COX-2 induced in ulcerated gastric mucosa is involved in the defense and repairing mechanisms of the mucosa and that its inhibition by a selective COX-2 inhibitor delays ulcer healing, we have also shown, in human stomach, that COX-2 is exclusively expressed in gastric mesenchymal cells such as fibroblasts and in inflammatory cells of the ulcer bed and margins, suggesting that COX-2 expressed in mesenchymal cells at the ulcer margin plays a key role in the ulcer repair process (Miura et al., 2004).

Several authors associate the antiulcerogenic process with healing of chronic ulcers and participation of EGF. Growth factors and their receptors play important roles in cell proliferation and migration, repair of the tissue injury and ulcer healing, considering that EGF is effective at protecting the gastric mucosa from acetic acid-induced gastric lesions, it is reasonable to assume that this factor limits mucosal damage caused by ulcerogenic agents, probably aiding early mucosal restoration (Konturek et al., 1992). The increase in COX-2 (Figure 1A) and EGF (Figure 1B) expression in rats treated with $\mathrm{BB}$ may indicate a participation of this protein in restoring the gastric mucosa.

Acetic acid induces gastric ulcers by a perforative nature, spread over a large area that does not heal with time, the application of glacial acetic acid to the gastric serous membrane caused ulcer with 
wall-encircled deep craters (Hiruma-Lima et al., 2006). Postoperative treatment with BB (100 mg/kg) for fourteen consecutive days demonstrated, for the first time, that BB accelerated ulcer healing. On the day 14 after surgery, the percentage of rats with cicatrized ulcers in both experimental groups was significantly higher than that of the control group. In addition, BB $(100 \mathrm{mg} / \mathrm{kg})$ significantly decreased the mean area of chronic ulcer (Figure 2).
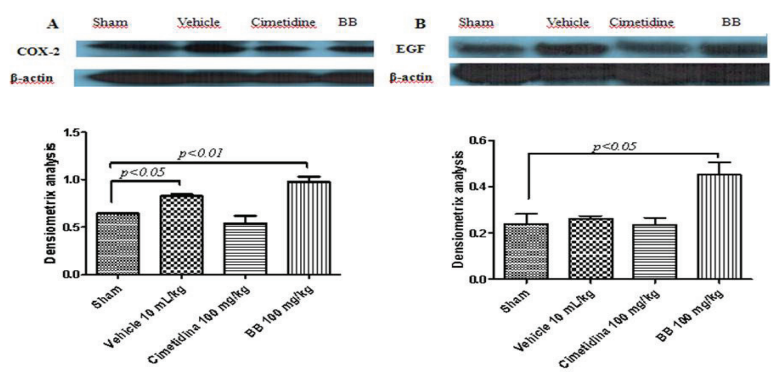

Figure 1. Representative Western blot analysis COX-2 (A) and EGF (B) proteins. Densitometric data were studied following normalization to the control ( $\beta$-actin house-keeping gene). The results are representative of three experiments performed on different samples and data are expressed as mean \pm SEM.

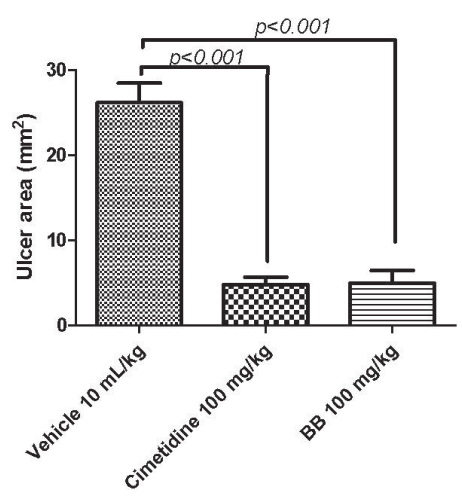

Figure 2. Effects of chronic administration of BB $100 \mathrm{mg} /$ $\mathrm{kg}$ on ulcer healing in rats with chronic ulcer induced by 0.05 $\mathrm{mL}(\mathrm{v} / \mathrm{v})$ of a $30 \%$ acetic acid solution. This dose significantly decreased the severity and extent of area damaged by acetic acid at fourteen days. Results were expressed as mean \pm SEM. Data were analyzed by ANOVA followed by Tukey's test and compared to vehicle.

On toxicological parameters, there were no significant differences in body weight development (data not shown) or organ weights (Figure 3) for all groups. No macroscopic abnormalities were detected in the examined organs. No mortality observed in any treatment group during the fourteen days of study.

Ligation of the pylorus model produces accumulation of gastric juice with gastric acid hypersecretion which generates the wound in the mucosa. The hypersecretion of gastric acid is one of the major pathogenic factors of gastric ulcer (Hiruma-Lima et al., 2009; Tuorkey \& Karolin, 2009). The gastric juice obtained from pylorus-ligated rats was used to analyze the gastric biochemical parameters by oral or intraduodenal $\mathrm{BB}$ administration. Administration of BB (100 mg/kg) by different routes (oral and intraduodenal) showed no significant difference in the assessed parameters of the gastric juice (data not shown). Thus, an antisecretory activity may not be involved in this protection.

Intracellular antioxidant, such as GR is critical for cellular protection in gastric tissues, GSH and GR have a prominent role in tissue repairing when reactive oxygen species (ROS) are involved, it was reported that, in humans, a reduction in gastric GR can occur following ethanol consumption and GR pretreatment could subside the gastric damage (Morais et al., 2010). It was also reported that an increase in GSH levels show a parallel to the adaptation phenomenon, the higher the GSH level, the less the damage occurred, GSH and other antioxidants prevented tissue damage by keeping ROS at physiological levels (Polat et al., 2010). The results indicated that GSH (Figure 4) and GR (Table 3) levels increased if compared to the control group, demonstrating a possible antioxidant capacity of BB.

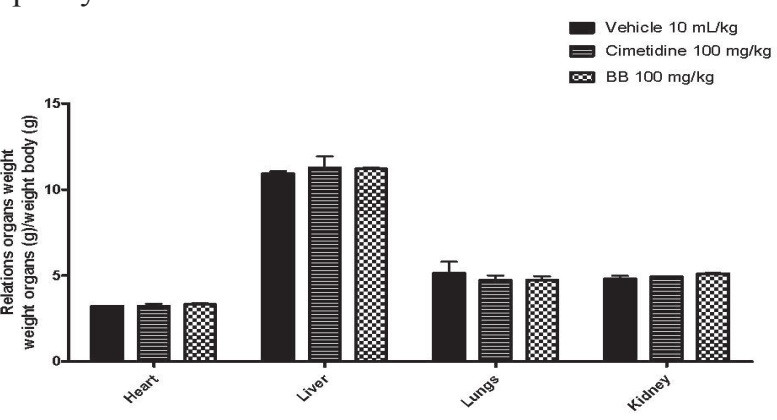

Figure 3. Organs weight in rats treated orally with vehicle, lansoprazole $(30 \mathrm{mg} / \mathrm{kg})$ or BB $(100 \mathrm{mg} / \mathrm{kg})$ for fourtenn days after ulcer formation by acetic acid solution injected into the stomach.

MPO exists in polymorphnuclear leukocyte cells (PNL) and catalyses the formation of toxic hypochlorous acid $(\mathrm{HOCl})$ from hydrogen peroxide, in addition, PNL excessively produce superoxide anion $\left(\mathrm{O}_{2}^{-}\right)$and hydroxyl radical $\left(\mathrm{OH}^{-}\right)$, which are free oxygen radicals, excessive production of MPO and other reactive radicals cause oxidative damage; which is represented by measuring lipid peroxidation levels, an important reason for cell membrane damage; MDA is the final product of lipid peroxidation and is used to determine lipid peroxidation levels (Dursun et al., 2009). Gastric MPO (Figure 5) and MDA (Figure 6) were increased by indomethacin application and decreased by $\mathrm{BB}(100 \mathrm{mg} / \mathrm{kg})$ administration, another indicator of a possible antioxidant activity of the oil, which still needs deeper studies for a complete understanding. 
Ethanol may enhance the damage associated with the increased steady-state levels of ROS and could act by increasing the activity of SOD. Previous studies have shown SOD activity increased values in the ethanol treated group compared to control rats, suggesting that oxidative stress condition can increase the levels of $\mathrm{O}_{2}{ }^{-}$or induce the activity of the enzyme (Repetto et al., 2003). Some researchers reported that ethanol increases GPx activity (Suleyman et al., 2010). The BB maintained the same levels of SOD (Table 3) and GPx (Table 3) of the sham group, this effect suggests that $\mathrm{BB}$ could decrease the oxidative stress condition generated by ethanol.

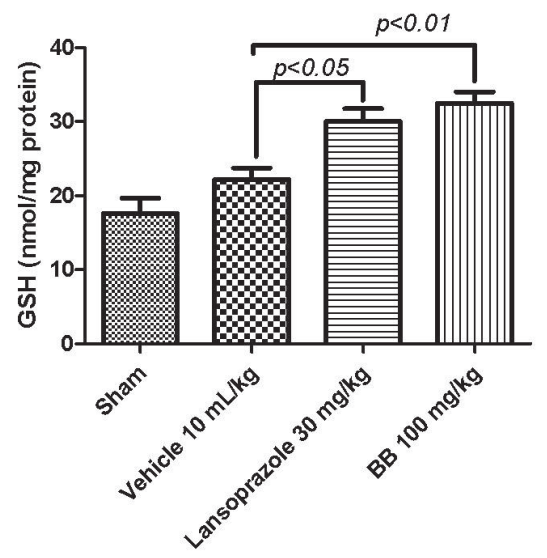

Figure 4. Sulfhydryl contents in the gastric mucosa of rats pretreated with $\mathrm{BB}(100 \mathrm{mg} / \mathrm{kg})$ and submitted to absolute ethanol-induced ulcerative lesions. Results were expressed as mean \pm SEM. Data were analyzed by ANOVA followed by Tukey's test and compared to vehicle.

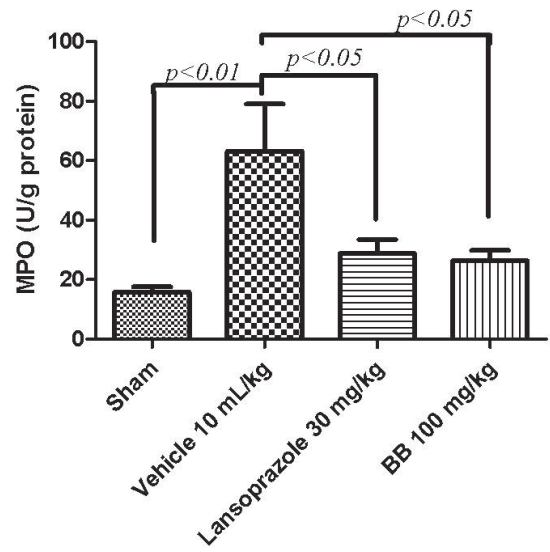

Figure 5. Effect of BB $(100 \mathrm{mg} / \mathrm{kg})$ on MPO activity in the gastric mucosa of rats submitted to ethanol. Results were expressed as mean \pm SEM. Data were analyzed by ANOVA followed by Tukey's test and compared to vehicle.

\section{Conclusion}

In conclusion, all these results taken, together, show, for the first time, that BB exerts gastroprotective activity, as evidenced by the significant inhibition of the formation of ulcers induced by different models, these protection could be attributed to an increased COX-2 and EGF expression and to the antioxidant properties. This antioxidant activity could be influenced by the presence of monoterpenes in the chemical structure of BB. However, further studies are required to investigate the active compounds and elucidate the mechanisms involved in the effects.

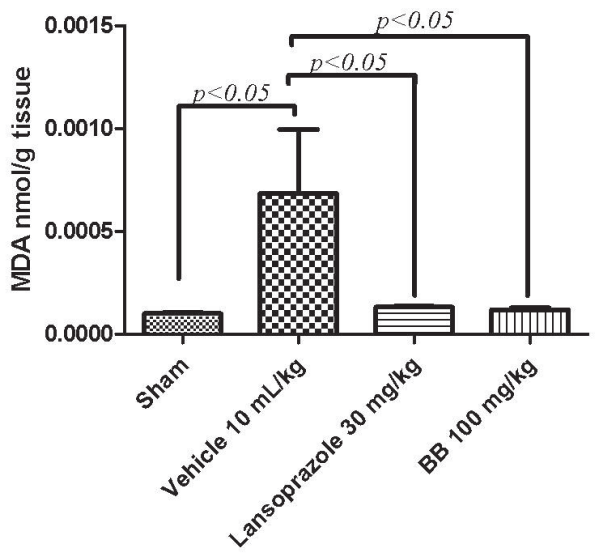

Figure 6. Effect of BB $(100 \mathrm{mg} / \mathrm{kg})$ on levels of MDA in ethanoltreated rats. Results were expressed as mean \pm SEM Data were analyzed by ANOVA followed by Tukey's test and compared to vehicle.

Table 3. Effect of BB $(100 \mathrm{mg} / \mathrm{kg})$ on stomach antioxidants enzymes and the levels of MDA in ethanol-treated rats. Results were expressed as mean \pm SEM. Data were analyzed by ANOVA followed by Tukey's test and compared to vehicle. ${ }^{*} p<0.05$.

\begin{tabular}{lccc}
\hline Treatments & $\begin{array}{c}\text { SOD } \\
\text { (U/mg protein) }\end{array}$ & $\begin{array}{c}\text { GPx } \\
\text { (nmol/min/mg } \\
\text { of protein) }\end{array}$ & $\begin{array}{c}\mathrm{GR} \\
(\mathrm{mmol} / \mathrm{min} / \mathrm{mg} \\
\text { of protein) }\end{array}$ \\
\hline Sham & $1.9 \pm 0.2$ & $1.8 \pm 0.3$ & $0.9 \pm 0.1$ \\
Vehicle & $3.4 \pm 0.5$ & $3.1 \pm 0.3$ & $0.9 \pm 0.1$ \\
Lansoprazole & $2.2 \pm 0.1 *$ & $1.9 \pm 0.2 *$ & $1.5 \pm 0.1^{*}$ \\
BB $(100 \mathrm{mg} / \mathrm{kg})$ & $2.0 \pm 0.1 *$ & $1.8 \pm 0.2^{*}$ & $1.6 \pm 0.1^{*}$ \\
\hline
\end{tabular}

\section{References}

Abdel-Salam OM, Czimmer J, Debreceni A, Szolcsanyi J, Mozsik G 2001. Gastric mucosal integrity: gastric mucosal blood flow and microcirculation. An overview. J Physiol Paris 95: 105-127.

Aidi Wannes W, Mhamdi B, Sriti J, Ben Jemia M, Ouchikh O, Hamdaoui G, Kchouk ME, Marzouk B 2010. Antioxidant activities of the essential oils and methanol extracts from myrtle (Myrtus communis var. italica L.) leaf, stem and flower. Food Chem Toxicol 48: 1362-1370.

Aragão GF, Carneiro LMV, Junior APF, Vieira LC, Bandeira PN, Lemos TL, Viana GS 2006. A possible mechanism for anxiolytic and antidepressant effects of alpha- and beta-amyrin from Protium heptaphyllum (Aubl.) March. Pharmacol Biochem Be 85: 827-834.

Barbastefano V, Cola M, Luiz-Ferreira A, Farias-Silva E, HirumaLima CA, Rinaldo D, Vilegas W, Souza-Brito AR 2007. 
Vernonia polyanthes as a new source of antiulcer drugs. Fitoterapia 78: 545-551.

Bandyopadhyay D, Biswas K, Bhattacharyya M, Reiter RJ, Banerjee RK 2001. Gastric toxicity and mucosal ulceration induced by oxygen-derived reactive species, protection by melatonin. Curr Mol Med 1: 501-513.

Bandyopadhyay D, Biswas K, Bhattacharyya M, Reiter RJ, Banerjee RK 2002. Involvement of reactive oxygen species in gastric ulceration, protection by melatonin. Indian J Exp Biol 40: 693-705.

Bhattacharjee M, Bhattacharjee S, Gupta A, Banerjee RK 2002. Critical role of an endogenous gastric peroxidase in controlling oxidative damage in $H$. pylori-mediated and non-mediated gastric ulcer. Free Radical Biol Med 32: 731-743.

Bradford MM 1976. A rapid and sensitive method for the quantitation of microgram quantities of protein utilizing the principle of protein-dye binding. Anal Biochem 72: 248-254. Carlberg I, Mannervick B 1985. Glutathione reductase. Methods Enzymol 113: 484-499.

Cechinel-Filho V, Yunes RA 2001. Estudo químico de plantas medicinais orientado para a análise biológica. Obtenção, determinação e modificação estrutural de compostos bioativos. In Yunes RA, Calixto JB (eds.) Plantas medicinais sob a ótica da química medicinal moderna. Chapecó: Argos Editora Universitária.

Dursun H, Bilici M, Albayrak F, Ozturk C, Saglam MB, Alp HH, Suleyman H 2009. Antiulcer activity of fluvoxamine in rats and its effect on oxidant and antioxidant parameters in stomach tissue. BMC Gastroenterol 20: 9-36.

Faure P, Lafond JL 1995. Measurement of plasma sulfhydryl and carbonyl groups as a possible indicator of protein oxidation. In Analysis of free radicals in biological systems. Boston: Verla.

Franke A, Teyssen S, Singer MV 2005. Alcohol-related diseases of the esophagus and stomach. Dig Dis 25: 204-213.

Hiruma-Lima CA, Batista LM, de Almeida AB, de Pietro Magri L, dos Santos LC, Vilegas W, Souza Brito AR 2009. Antiulcerogenic action of ethanolic extract of the resin from Virola surinamensis Warb. (Myristicaceae). J Ethnopharmacol 122: 406-409.

Hiruma-Lima CA, Calvo TR, Rodrigues CM, Andrade FD, Vilegas W, Brito AR 2005. Antiulcerogenic activity of Alchornea castaneaefolia: effects on somatostatin, gastrin and prostaglandin. J Ethnopharmacol 104: 215224.

Hiruma-Lima CA, Santos LC, Kushima H, Pellizzon CH, Silveira GG, Vasconcelos PCP 2005. Qualea grandiflora, a Brazilian "Cerrado" medicinal plant presents an important antiulcer activity. J Ethnopharmacol 104: 207214.

Khan HA 2004. Computer-assisted visualization and quantitation of experimental gastric lesions in rats. J Pharmacol Toxicol 49: 89-95.

Konturek SJ, Brzozowski T, Majka J, Dembinski A, Slomiany A, Slomiany BL 1992. Transforming growth factor alpha and epidermal growth factor in protection and healing of gastric mucosal injury. Scand J Gastroenterol 27: 649655.

Laciar A, Ruiz ML, Flores RC, Saad JR A 2009. Antibacterial and antioxidant activities of the essential oil of Artemisia echegarayi Hieron. (Asteraceae). Rev Argent Microbiol 41: 226-231.

Lehne RA 1998. Pharmacology for Nursing Care. Philadelphia: W.B. Saunders.

Luiz-Ferreira A, Almeida AC, Cola M, Barbastefano V, Almeida $\mathrm{AB}$, Batista LM, Farias-Silva E, Pellizzon CH, HirumaLima CA, Santos LC, Vilegas W, Brito AR 2003. Mechanisms of the gastric antiulcerogenic activity of Anacardium humile St. Hil on ethanol-induced acute gastric mucosal injury in rats. Molecules 15: 7153-7166.

Mayty P, Biswas K, Roy S, Barnergee RK, Bandyopadhyay U 2003. Smoking and pathogenesis of gastroduodenal ulcer-recent mechanistic update. Mol Cell Biochem 253: 329-338.

Miura S, Tatsuguchi A, Wada K, Takeyama H, Shinji Y, Hiratsuka T, Futagami S, Miyake K, Gudis K, Mizokami Y, Matsuoka T, Sakamoto C 2004. Cyclooxygenase2-regulated vascular endothelial growth factor release in gastric fibroblasts. Am J Physiol Gastrointest Liver Physiol 287: 444-451.

Moleiro FC, Andreo MA, Santos R de C, Moraes T de M, Rodrigues CM, Carli CB, Lopes FC, Pellizzon CH, Carlos IZ, Bauab TM, Vilegas W, Hiruma-Lima CA 2009. Mouriri elliptica: Validation of gastroprotective, healing and anti-Helicobacter pylori effects. J Ethnopharmacol 123: 359-368.

Morais TC, Pinto NB, Carvalho KM, Rios JB, Ricardo NM, Trevisan MT, Rao VS, Santos FA 2010. Protective effect of anacardic acids from cashew (Anacardium occidentale) on ethanol-induced gastric damage in mice. Chem Biol Interact 183: 264-269.

Morimoto Y, Oshima S, Hara H, Sukamoto T 1991. Effects of the new anti-ulcer agent KB-5492 on experimental gastric mucosal lesions and gastric mucosal defensive factors, as compared to those of teprenone and cimetidine. Jpn $J$ Pharmacol 57: 495-505.

Mota KS, Dias GE, Pinto ME, Luiz-Ferreira A, Souza-Brito AR, Hiruma-Lima CA, Barbosa-Filho JM, Batista LM 2009. Flavonoids with gastroprotective activity. Molecules 14: 979-1012.

Odabasoglu F, Cakir A, Suleyman H, Aslan A, Bayir Y, Halici M, Kazaz C 2006. Gastroprotective and antioxidant effects of usnic acid on indomethacin-induced gastric ulcer in rats. J Ethnopharmacol 103: 59-65.

Ohkawa H, Nobuko O, Yagi K 1979. Assay for lipid peroxidation in animal tissues by thiobarbituric acid reaction. Ana Biochemical 95: 351-358.

Okabe S, Amagase K 2005. An overview of acetic acid ulcer models -the history and state of the art of peptic ulcer research. Biol Pharm Bull 28: 1321-1341.

Oliveira FA, Costa CL, Chaves MH, Almeida FR, Cavalcante IJ, Lima AF, Lima RC Jr, Silva RM, Campos AR, Santos FA, Rao VS 2005. Attenuation of capsaicin-induced acute and visceral nociceptive pain by $\alpha$ and $\beta$ amyrin, a triterpene mixture isolated from Protium heptaphyllum resin in mice. Life Sci 77: 2942-2952.

Polat B, Suleyman H, Alp HH 2010. Adaptation of rat gastric tissue against indomethacin toxicity. Chem Biol Interact 186: 82-89.

Puscas I, Puscas C, Coltau M, Pasca R, Torres J, Márquez M, et al 1997. Comparative study of the safety and efficacy 
of ebrotidine versus ranitidine and placebo in the prevention of piroxicam-induced gastroduodenal lesions. Arzneimittelforschung 47: 568-572.

Rao CHV, Ojha SK, Radhakrishnan K, Govindarajan R, Rastogi S, Mehrotra S, Pushpangadan P 2004. Antiulcer activity of Utleria salicifolia rhizome extract. J Ethnopharmacol 91: 243-249.

Repetto M, María A, Guzmán J, Giordano O, Llesuy S 2003. Protective effect of Artemisia douglasiana Besser extracts in gastric mucosal injury. $J$ Pharm Phamacol 55: 551-557.

Schmeda-Hirschmann G, Yesilada E 2005. Traditional medicine and gastroprotective crude drugs. $J$ Ethnopharmacol 22: 61-66.

Shay H, Komarov SA, Fels SS, Meranze D, Gruenstein M, Siplet H 1945. A simple method for the uniform production of gastric ulceration in the rat. $J$ Gastroenterol 5: 43-61.

Singh P, Shukla R, Prakash B, Kumar A, Singh S, Mishra PK, Dubey NK 2010. Chemical profile, antifungal, antiaflatoxigenic and antioxidant activity of Citrus maxima Burm. and Citrus sinensis (L.) Osbeck essential oils and their cyclic monoterpene, DL-limonene. Food Chem Toxicol 48: 1734-1740.

Souza-Brito ARM 1994. Manual de ensaios toxicológicos in vivo. Campinas: Editora da Unicamp.

Suleyman H, Albayrak A, Bilici M, Cadirci E, Halici Z 2010. Different mechanisms in formation and prevention of indomethacin-induced gastric ulcers. Inflammation 33:
224-234.

Takagi K, Okabe S, Saziki R 1969. A new method for the production of chronic gastric ulcer in rats and the effect of several drugs on its healing. Jpn J Pharmacol 19: 418426.

Tarnawski AS 2005. Cellular and molecular mechanisms of gastrointestinal ulcer healing. Dig Dis Sci 50: 24-33.

Tuorkey M, Karolin K 2009. Antiulcer activity of curcumin on experimental gastric ulcer in rats and its effect on oxidative stress/antioxidant, IL6 and enzyme activities. Biomed Environ Sci 22: 488-495.

Yoshikawa T, Naito Y, Kishi A, Tomii T, Kaneko T, Iinuma S, Ichikawa H, Yasuda M, Takahashi S, Kondo M 1993. Role of active oxygen, lipid peroxidation, and antioxidants in the pathogenesis of gastric mucosal injury induced by indomethacin in rats. Gut 34: 732-737.

Winterbourn CC, Hawkins RE, Brian M, Carrel RW 1995. The estimulation of red cell superoxide dismutase activity. $J$ Lab Clin Med 85: 337-341.

\section{*Correspondence}

Deborah A. O. Valim Araujo

Departamento de Farmacologia, Faculdade de Ciências Médicas, Universidade Estadual de Campinas, 13084-971Campinas-SP, Brazil

abrito@unicamp.br

Tel.: +551935216192

Fax: $+55-1935216184$ 